\title{
ПОЛУЧЕНИЕ КАЧЕСТВЕННОГО СОРБЕНТА ИЗ ОТХОДОВ РИСА И НЕФТЕШЛАМА
}

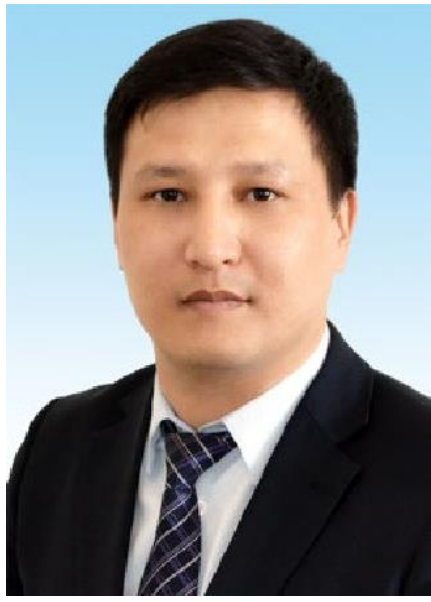

H.O. АППАЗОВ ${ }^{1}$

кандидат химических наук, профрессор, директор Института химических исследований и технологий, http://orcid.org/0000-0001-8765-3386

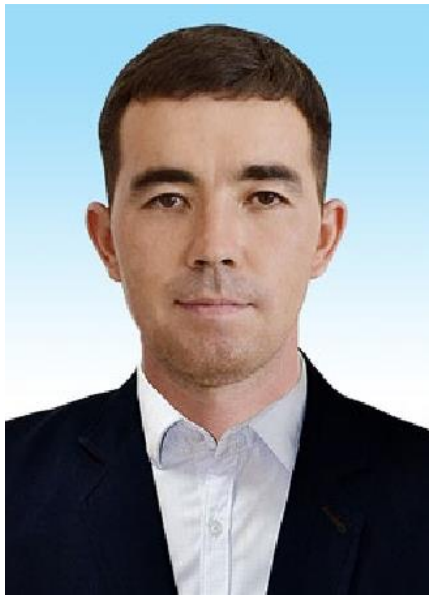

Н.И. АКЫЛБЕКОВ ${ }^{1 *}$,

$\mathrm{PhD}$, руководитель лаборатории инженерного профриля «Физикохимические методы анализа», заместитель директора института химических исследований и технологий, http://orcid.org/0000-0002-7584-9741

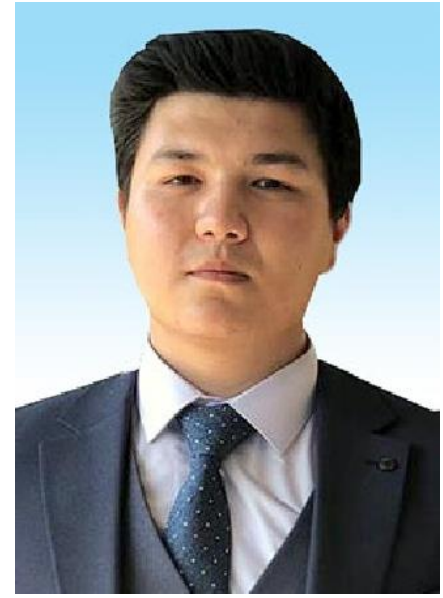

Б.М. БАЗАРБАЕВ ${ }^{1}$,

инженер лаборатории инженерного профиля «Физикохимические методы анализа», http://orcid.org/0000-0003-1574-8145

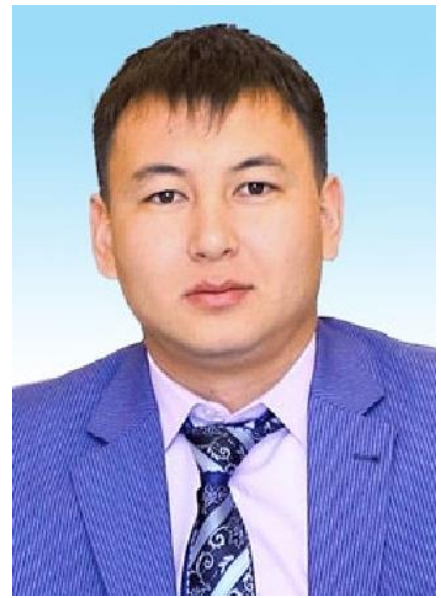

\section{Р.У. ЖАППАРБЕРГЕНОВ ${ }^{1}$,}

магистр сельскохозяйственных наук, научный сотрудник лаборатории инженерного профиля «Физикохимические методы анализа», http://orcid.org/0000-0002-0567-3226

*Автор для переписки. E-mail:nurgali_089@mail.ru 


\author{
C.А. КАНЖАР ${ }^{1}$, студент по специальности \\ «Химическая технология органических веществ», \\ https://orcid.org/0000-0003-4553-3049
}

\title{
Б.М. ДИЯРОВА², PhD-докторант по специальности «Химия», https://orcid.org/0000-0002-1086-369X
}

\author{
${ }^{1}$ Кызылординский государственный университет им. Коркыт Ата, \\ Республика Казахстан, 120014, г. Кызылорда, ул. Айтеке би, 29А \\ ${ }^{2}$ Казахский национальный женский педагогический университет, \\ Республика Казахстан, 050000, г. Алматы, ул. Айтеке би, 99
}

Проведен со-термолиз рисовой шелухи и соломы с нефртешламом с целью получения широко применяемого адсорбента - активированного угля. Карбонизацию проводили в трубчатой печи, изготовленной из нержавеющей стали при температуре $500^{\circ} \mathrm{C}$ и активацию карбонизата осуществляли водяным паром при температуре $800^{\circ} \mathrm{C}$. Изучено влияние соотношения исходных компонентов сырья (шелуха / солома:нефртешлам) на свойства продукта. Оптимальным соотношением для со-термолиза шелуха: нефтешлам является 9:1 (по массе), соответственно. Оптимальным условием получения активированного угля со-термолизом рисовой соломы и нефтешлама является температура карбонизации $500^{\circ} \mathrm{C}$ с продолжительностью 100 мин., активации карбонизата при температуре $850^{\circ} \mathrm{C}$ и при соотношении вода: карбонизат = 2:1. Изучены такие показатели, как адсорбционная активность по йоду, суммарный объем пор по воде, массовая доля влаги и насыпная плотность. Микроструктуры полученных активированных углей изучали на сканирующем растровом электронном микроскопе. Активированный уголь, полученный совместной переработкой рисовой шелухи и нефтешлама в соотношениях 9:1, соответствует активированному углю марки ДАК. Полученный продукт на основе рисовой соломы и нефртешлама соответствует активированным углям марки БАУ-МФ, БАУ-А и БАУ-АЦ.

КЛЮЧЕВЫЕ СЛОВА: активированный уголь, рисовая шелуха, рисовая солома, нефтешлам, со-термолиз, карбонизация, активация карбонизата.

\section{КУРІШ ЖӘНЕ МҰНАЙ ҚАЛДЫҚТАРЫНАН САПАЛЫ СОРБЕНТ АЛУ}

Н.О. АППАЗОВ ${ }^{1}$, химия ғылымдарының кандидаты, профессор, Химиялық зерттеулер және технологиялар институтының директоры. http://orcid.org/0000-0001-8765-3386

Б.М. БАЗАРБАЕВ ${ }^{1}$, «Физика-химиялық талдау әдістері» инженерлік бейіндегі зертхананың инженері. http://orcid.org/0000-0003-1574-8145

Н.И. АКЫЛБЕКОВ ${ }^{1 *}, \mathrm{PhD}$, «Физика-химиялық талдау әдістері» инженерлік бейіндегі зертхана жетекшісі-химиялық зерттеулер және технологиялар институты директорының орынбасары. http://orcid.org/0000-0002-7584-9741

Р.У. ЖАППАРБЕРГЕНОВ ${ }^{1}$, ауыл шаруашылығы ғылымдарының магистрі, «Физика-химиялық талдау әдістері» инженерлік бейіндегі зертхананың ғылыми қызметкері. http://orcid. org/0000-0002-0567-3226

С.А. КАНЖАР ${ }^{1}$, «Органикалық заттардың химиялық технологиясы» мамандығының студенті. https://orcid.org/0000-0003-4553-3049

Б.М. ДияРОВА², «Химия» мамандығы бойынша PhD-докторант. https://orcid.org/0000-00021086-369X 
${ }^{1}$ Қорқыт Ата атындағы Қызылорда мемлекеттік университеті, Қазақстан Республикасы, 120014, Қызылорда қ., Әйтеке би көшесі, 29A

²Қазақ ұлттық қыздар педагогикалық университеті, Қазақстан Республикасы, 050000, Алматы қ., Айтеке би көшесі, 99

Кең қолданылатын адсорбент - белсендірілеен көмір алу мақсатында күріш қауызы мен сабанын мұнай шламымен со-термолиздеу үрдісі жүргізілді. Карбонизация $500^{\circ} \mathrm{C}$ температурада тотықпайтын болаттан жасалған түтікті пеште жүргізілді, карбонизатты белсендіру су буымен $800^{\circ} \mathrm{C}$ температурада іске асырылды. Шикізаттың бастапқы компоненттері қатынасының (күріш қауызы / сабаны:мұнай шламы) өнім қасиетіне әсері зерттелді. Со-термолиздеу нәтижесі бойынша оңтайлы қатынас күріш қауызы: мұнай шламы = 9:1 (массасы бойынша) болып табылады. Күріш сабаны мен мұнай шламын со-термолиздеу арқылы алудың оңтайлы жағдайы: карбонизациялау температурасы $500^{\circ} \mathrm{C}$ ұзақтылығы 100 мин, карбонизатты белсендіру $850^{\circ} \mathrm{C}$, су: карбонизат қатынасы 2:1 болып табылады. Йод бойынша адсорбциялық белсенділік, су бойынша жалпы кеуектер көлемі, судың массалық үлесі және ұнтақты тығыздық тәрізді көрсеткіштер зерттелді. Алынған белсендірілген көмірлердің микроқұрылымы сканерлеуші растрлы электронды микроскоп көмегімен зерттелді. Күріш қауызы мен мұнай шламы 9:1 қатынаста бірге өңдеу арқылы алынған белсендірілген көмір ДАКмаркасына сәйкес келеді. Күріш сабаны мен мұнай шламын өңдеу арқылы алынған өнім БАУ-МФ, БАУ-А және БАУ-Ац маркалы белсендірілген көмірлерге сәйкес келеді.

ТҮЙІн СөзДЕР: белсендірілеен көмір, күріш қауызы, күріш сабаны, мұнай шламы, сотермолиз, карбонизация, карбонизатты белсендіру.

\section{OBTAINING QUALITATIVE SORBENT FROM RICE WASTE AND OIL SLUDGE}

N.O. APPAZOV ${ }^{1}$, candidate of chemical sciences $(\mathrm{PhD})$, professor, Director of the Institute of Chemical Research and Technology. http://orcid.org/0000-0001-8765-3386

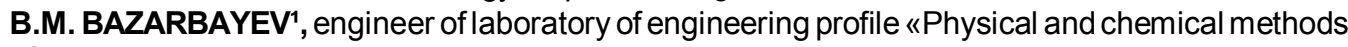
of analysis». http://orcid.org/0000-0003-1574-8145

N.I. AKYLBEKOV ${ }^{\star *}, \mathrm{PhD}$, Head of laboratory of engineering profile «Physical and chemical methods of analysis»-Deputy Director of the Institute of Chemical Research and Technology. http://orcid. org/0000-0002-7584-9741

R.U. ZHAPPARBERGENOV', Master of Agricultural Sciences, Researcher of laboratory of engineering profile «Physical and chemical methods of analysis». http://orcid.org/0000-0002-0567-3226

S.A. KANZHAR', student majoring in Chemical Technology of Organic Substances. https://orcid. org/0000-0003-4553-3049

B.M. DIYAROVA², PhD student in Chemistry. https://orcid.org/0000-0002-1086-369X

${ }^{1}$ Korkyt Ata Kyzylorda State University,

Republic of Kazakhstan, 120014, Kyzylorda, 29A Aiteke bie str.

${ }^{2}$ Kazakh State women's teacher training university,

Republic of Kazakhstan, 050000, Almaty, Ayteke bi, 99

Co-thermolysis of rice husk and straw with oil sludge was carried out in order to obtain a widely used adsorbent - activated carbon. Carbonization was carried out in a tubular furnace made of stainless steel at a temperature of $500^{\circ} \mathrm{C}$ and the activation of carbonization was carried out with water vapor at a temperature of $800^{\circ} \mathrm{C}$. The influence of the ratio of the initial components of the raw material (husk / straw:oil sludge) on the properties of the product was studied. The 
optimal ratio for co-thermolysis of the husk: oil sludge is 9:1 (by weight), respectively. The optimal condition for the production of activated carbon by co-thermolysis of rice straw and oil sludge is a carbonization temperature of $500^{\circ} \mathrm{C}$ with a duration of $100 \mathrm{~min}$, activation of the carbonizate at a temperature of $850^{\circ} \mathrm{C}$ and with a ratio of water:carbonizate $=2: 1$. Indices such as iodine adsorption activity, total pore volume in water, mass fraction of moisture, and bulk density were studied. The microstructures of the obtained activated carbons were studied on a scanning scanning electron microscope. Activated carbon obtained by the joint processing of rice husk and oil sludge in a ratio of 9:1 corresponds to activated carbon brand DAK. The resulting product based on rice straw and oil sludge corresponds to the activated carbons BAU-MF, BAU-A and BAU-Ats.

KEYWORDS: activated carbon, rice husk, rice straw, oil sludge, co-thermolysis, carbonization, activating of carbonizate.

\section{A}

ктивированный уголь находит широкое практическое применение в очистке воздуха и газов, в обесцвечивании и очистке жидкостей и растворов, в водоподготовке, в качестве катализаторов и носителей катализаторов, в медицине, в табачном производстве и т. д. [1].

Важнейшим сырьем для получения активного угля являются: древесина (в виде опилок), древесный уголь, торф, торфяной кокс, каменные и бурые угли, а также полукокс бурых углей. Известны способы получения активированного угля из фруктовых косточек, скорлупы орехов, сельскохозяйственных отходов, отходов бумажного производства, мусора, осадков сточных вод, изношенных резиновых покрышек, отходов производства синтетических полимеров и т. д., которые не нашли широкого промышленного применения [1-5].

Известны способы получения активированного угля из растительных отходов, в частности из отходов ячменя (шелуха и некондиционное зерно) и из соломы рапса $[6,7]$. Авторы $[8,9]$ в исследованиях использовали кукурузные початки в качестве сырья для производства активированного угля. Активацию проводили с использованием диоксида углерода при температурах $800-900^{\circ} \mathrm{C}$, времени активации 20-120 мин. и степени обжига $1-71 \%$.

Имеются работы по получению высокопористого активного угля из рисовой шелухи, который имеет селективную сорбционную активность на ионы свинца [10, 11]. Имеются сведения, что совместная переработка рисовой шелухи с политетрафторэтиленом показывает высокую пористую структуру [3].

Авторами [12] получен активированный уголь из рисовой шелухи, карбонизацию проводят при температуре $500-700^{\circ} \mathrm{C}$ с выдержкой 100-120 мин., активацию осуществляют при температуре $780-800^{\circ} \mathrm{C}$ при расходе водяного пара 2,0-2,5 кг на 1 кг карбонизированного продукта. Адсорбционная активность по йоду активированного угля, полученного данным способом, составляет 20-25\%. Недостатком данного способа является низкая адсорбционная активность.

Активированные угли получены из рисовой шелухи путем активации с помощью фосфорной кислоты [13-16], а также получен активированный уголь из рисовой шелухи методом активации с фосфорной кислотой в одностадийном процессе [17].

Ранее нами был получен активированный уголь из рисовой соломы и шелухи [18], а также совместной переработкой рисовой шелухи и соломой с нефтешламом [19-21]. Из рисовой шелухи получен аморфный диоксид кремния высокой чистоты в условиях сверхвысокочастотного облучения [22]. 
Нефтешлам представляет собой эмульсию нефтепродуктов в воде, стабилизированную твердой фазой, состоящих в основном из твердых песчаных, глинистых частиц, частиц гидроксидов металлов, карбонатов щелочноземельных, сульфидов железа, элементарной серы. Разработанная ресурсосберегающая технология гранулированного пористого теплоизоляционного материала типа «керамзит», основанная на рациональном использовании некондиционного природного сырья и отходов нефтедобычи, позволяет отказаться от дорогостоящей энерговыделяемой добавки угля, нефти, снизить энергозатраты на сушку и обжиг изделий на 25-30\%. Авторами установлено, что процесс горения нефтешлама в составе конгломератной смеси позволяет повысить температуру внутри печи и ускорить процесс вспучивания керамической массы за счет выгорания асфальтенов, масел, смолы [23]. В результате исследований авторы разрабатывали новые препараты для очистки загрязненных нефтью почв в условиях жаркого климата [24].

При проведении со-термолиза используются многокомпонентные смеси или композиты, различных по своей природе органических материалов с целью получения синергизма термолиза компонентов и, соответственно, улучшения выхода и селективности вторичных продуктов. Процессы со-карбонизации смесей техногенного сырья и природных углеродных материалов с целью получения твердых пористых сорбентов - относительно новая и малоизученная область применения со-термолиза к задачам переработки органического сырья.

Проведен анализ нефтешламов с резервуаров Кумколь АО «ПетроКазахстан Кумколь Ресорсиз», базирующейся на территории Кызылординской области.

Изучение углеводородного состава нефтешлама проводили с помощью газового хромато-масс спектрометра Agilent 7890A/5975С (США).

Хроматографический анализ проведен согласно методике, приведенной в работе [25]. Условия хроматографирования при анализе углеводородов, выделенных из нефтешлама, приведены в таблице 1 .

\section{Таблица 1 - Условия хроматографирования при анализе углеводородов, выделенных из нефтешлама}

\begin{tabular}{|l|c|}
\hline \multicolumn{1}{|c|}{ Показатели } & Условия хроматографирования \\
\hline подвижная фаза (газ носитель) & гелий \\
\hline температура испарителя & $350^{\circ} \mathrm{C}$ \\
\hline сброс потока (Split) & $30: 1$ \\
\hline температура термостата колонки: & $70^{\circ} \mathrm{C}$ \\
начало - & $4^{\circ} \mathrm{C}$ в минуту \\
подъем температуры- & $290^{\circ} \mathrm{C}$ \\
конец- & 30 мин \\
\hline время удержания при этой температуре - & 85 мин \\
\hline общее время анализа & НР-5МS \\
\hline режим ионизации масс-детектора & 30 м \\
\hline Капиллярная хроматограсрическая колонка & методом электронного уда \\
\hline длина колонки & 0,25 мм \\
\hline внутренний диаметр & диметилполисилоксан (95\%), \\
\hline неподвижная фраза & метилфенилполисилоксан (5\%) \\
\hline
\end{tabular}




\section{экология}

Углеводородный состав пробы приведен в таблице 2.

\section{Таблица 2 - Групповой состав углеводородов по результатам хромато-масс спектрометрического анализа}

\begin{tabular}{|l|c|}
\hline $\begin{array}{l}\text { Группы углеводородов, содержащихся в } \\
\text { нефтешламе }\end{array}$ & $\begin{array}{c}\text { Количественное содержание, масс. \% } \\
\text { Нефтешлам с резервуаров Кумколь } \\
\text { АО «ПетроКазахстан Кумколь Ресорсиз» }\end{array}$ \\
\hline Парафины & 46,38 \\
\hline Неконденсированные циклопарафины & 27,71 \\
\hline $\begin{array}{l}\text { Конденсированные циклопарафрины с 2 } \\
\text { кольцами }\end{array}$ & 8,45 \\
\hline $\begin{array}{l}\text { Конденсированные циклопарафинны с } 3 \\
\text { кольцами }\end{array}$ & 6,92 \\
\hline Бензолы & 2,74 \\
\hline Нафтенобензолы & 0,10 \\
\hline Динафттенобензолы & 0,10 \\
\hline Нафталины & 3,66 \\
\hline Аценафтены & 2,96 \\
\hline Фенантрены & 0,98 \\
\hline
\end{tabular}

Результаты исследования реологических свойств нефтешлама приведены в таблице 3.

\section{Таблица 3 - Реологические свойства нестешлама}

\begin{tabular}{|c|c|}
\hline \multirow[b]{2}{*}{ Наименование показателей } & Показатели \\
\hline & $\begin{array}{c}\text { Нефтешлам с резервуаров Кумколь } \\
\text { АО «ПетроКазахстанКумкольРесорсиз» }\end{array}$ \\
\hline Плотность, кг / м³ при $20^{\circ} \mathrm{C}$ & 836,4 \\
\hline $\begin{array}{l}\text { Фракционный состав, \% об. } \\
200^{\circ} \mathrm{C} \\
300^{\circ} \mathrm{C} \\
350^{\circ} \mathrm{C}\end{array}$ & $\begin{array}{l}11 \\
39 \\
54\end{array}$ \\
\hline Массовая доля серы, \% & 0,024 \\
\hline Теплота сгорания, кДж / г & 44,987 \\
\hline Содержание механических примесей, \% & 0,027 \\
\hline Содержание хлористых солей, мг / дм³ & 28,46 \\
\hline
\end{tabular}

Рисовая шелуха и солома были измельчены до порошкового состояния на лабораторной мельнице.

Со-термолиз рисовой шелухи и нефтешлама в соотношениях 9:1, 8:2, 7:3, 6:4, 5:5 проводили в трубчатой печи, изготовленной из нержавеющей стали высотой 250 мм и внутренним диаметром 25 мм при температуре $500^{\circ} \mathrm{C}$ и активацией карбонизата водяным паром при температуре $800^{\circ} \mathrm{C}$.

В печь помещают смесь из 9 г рисовой соломы и 1 г нефтешлама (оптимальное соотношение согласно работе [19]), карбонизацию проводили при температурах 
$350-500^{\circ} \mathrm{C}$. Затем в нижней части трубчатой печи подключается сосуд для подачи пара воды при температуре $750-900^{\circ} \mathrm{C}$.

Поверхность полученных активированных углей изучали на растровом сканирующем электронном микроскопе JSM-6510 LV фирмы JEOL (Япония).

Свойства полученных активированных углей (адсорбционная активность по йоду, суммарный объем пор по воде, массовая доля влаги, насыпная плотность) определяли по известной методике [26-29].

Совместную переработку рисовой шелухи и нефтешлама проводили по общей методике: в трубчатую печь помещали смесь рисовой шелухи и нефтешлама в различных соотношениях (таблица 4), герметизировали и осуществляли карбонизацию со скоростью подъема температуры $10^{\circ} \mathrm{C}$ в минуту до $500^{\circ} \mathrm{C}$ и выдерживали при этой температуре 100 мин. Затем в нижней части трубчатой печи подключали сосуд для подачи пара воды с расходом 2:1 на массу карбонизата. Активацию проводили при температуре $800^{\circ} \mathrm{C}$.

Физико-химические показатели полученного активированного угля показаны в таблице 4.

\section{Таблица 4 - Совместная переработка рисовой шелухи и нефтешлама}

\begin{tabular}{|l|c|c|c|c|c|}
\hline \multicolumn{1}{|c|}{ Наименование показателя } & \multicolumn{5}{|c|}{ Результаты экспериментальных исследований } \\
\hline $\begin{array}{l}\text { Массовое соотношение рисовой } \\
\text { шелухи и нефтешлама }\end{array}$ & $9: 1$ & $8: 2$ & $7: 3$ & $6: 4$ & $5: 5$ \\
\hline Выход карбонизата, масс. \% & 42,7 & 40,6 & 36,8 & 33,7 & 33,0 \\
\hline $\begin{array}{l}\text { Выход активированного угля, } \\
\text { масс. \% }\end{array}$ & 35 & 32,4 & 29,4 & 26,6 & 26,2 \\
\hline $\begin{array}{l}\text { Адсорбционная активность по } \\
\text { йоду, \% }\end{array}$ & 46,99 & 43,18 & 38,10 & 31,75 & 26,67 \\
\hline $\begin{array}{l}\text { Суммарный объем пор по воде, } \\
\text { см³ г }\end{array}$ & 1,41 & 1,38 & 1,31 & 1,28 & 1,20 \\
\hline Массовая доля влаги, \% & 4,1 & 4,5 & 4,9 & 5,1 & 5,3 \\
\hline Насыпная плотность, г/ дм & 201,4 & 207,9 & 211,3 & 213,2 & 220,8 \\
\hline
\end{tabular}

Со-термолиз смеси рисовой соломы и нефтешлама проводили со скоростью подъема температуры $10^{\circ} \mathrm{C}$ в минуту до необходимой температуры $\left(350-500^{\circ} \mathrm{C}\right)$ и выдерживали при данных температурах 50-150 мин. Выход карбонизата при со-термолизе в различных условиях составил 27,9-32,5\%. Активацию карбонизата проводили парами воды с расходами воды на массу карбонизата 1-4:1 при температурах 750-900 C. Выход активированного угля составил 20,0-29,0\% от массы взятой смеси соломы и нефтешлама.

Оптимальным условием получения активированного угля со-термолизом рисовой соломы и нефтешлама является температура карбонизации $500^{\circ} \mathrm{C}$ с продолжительностью 100 мин., активации карбонизата при температуре $850^{\circ} \mathrm{C}$ и при соотношении вода:карбонизат $=2: 1$. Адсорбционная активность по йоду, полученного таким способом активированного угля, составляет 94,03\% (таблица 5).

Выход и физико-химические параметры полученного активированного угля см. в таблице 5. 
Таблица 5 - Со-термолиз рисовой соломы и нефтешлама

\begin{tabular}{|c|c|c|c|c|c|c|c|c|c|c|c|}
\hline \multirow{2}{*}{$\begin{array}{l}\text { Наименование } \\
\text { показателя } \\
\text { Температура } \\
\text { карбонизации, } \\
{ }^{\circ} \mathrm{C}\end{array}$} & \multicolumn{11}{|c|}{ Результаты экспериментальных исследований } \\
\hline & 500 & 350 & 400 & 450 & 500 & 500 & 500 & 500 & 500 & 500 & 500 \\
\hline $\begin{array}{l}\text { Продолжитель- } \\
\text { ность карбони- } \\
\text { зации, мин }\end{array}$ & 100 & 100 & 100 & 100 & 100 & 100 & 50 & 150 & 100 & 100 & 100 \\
\hline $\begin{array}{l}\text { Выход карбони- } \\
\text { зата, масс. \% }\end{array}$ & 31,1 & 32,5 & 31,6 & 30,8 & 31,1 & 31,1 & 31,6 & 27,9 & 31,1 & 31,1 & 31,1 \\
\hline $\begin{array}{l}\text { Температура } \\
\text { активации кар- } \\
\text { бонизата, }{ }^{\circ} \mathrm{C}\end{array}$ & 850 & 800 & 800 & 800 & 750 & 900 & 850 & 850 & 850 & 850 & 850 \\
\hline $\begin{array}{l}\text { Соотношение } \\
\text { вода:карбони- } \\
\text { зат }\end{array}$ & $2: 1$ & $2: 1$ & $2: 1$ & $2: 1$ & $2: 1$ & $2: 1$ & $2: 1$ & $2: 1$ & $3: 1$ & $4: 1$ & $1: 1$ \\
\hline $\begin{array}{l}\text { Выход активи- } \\
\text { рованного угля, } \\
\text { масс. \% }\end{array}$ & 22,1 & 25,2 & 24,6 & 27,3 & 28,3 & 24,0 & 22,4 & 20,0 & 25,3 & 25,0 & 29,0 \\
\hline $\begin{array}{l}\text { Адсорбционная } \\
\text { активность по } \\
\text { йоду, \% }\end{array}$ & 94,03 & 60,97 & 51,84 & 49,29 & 73,34 & 92,71 & 45,58 & 42,24 & 31,75 & 35,56 & 30,47 \\
\hline $\begin{array}{l}\text { Суммарный } \\
\text { объем пор по } \\
\text { воде, } \text { см³ } / \text { г }\end{array}$ & 2,12 & 1,43 & 1,99 & 0,98 & 1,93 & 1,35 & 0,94 & 1,51 & 1,09 & 1,13 & 2,20 \\
\hline $\begin{array}{l}\text { Массовая } \\
\text { доля влаги, \% }\end{array}$ & 0,06 & 0,52 & 0,85 & 0,41 & 0,58 & 1,26 & 7,20 & 0,32 & 1,68 & 1,09 & 2,33 \\
\hline $\begin{array}{l}\text { Насыпная плот- } \\
\text { ность, г / дм³ }\end{array}$ & 144,7 & 154,0 & 142,4 & 141,9 & 143,2 & 168,0 & 167,3 & 149,9 & 117,7 & 124,3 & 114,9 \\
\hline
\end{tabular}

Микрофотографии активированных углей приведены на рисунках 1 и 2, где можно увидеть развитую пористую структуру полученных сорбентов.

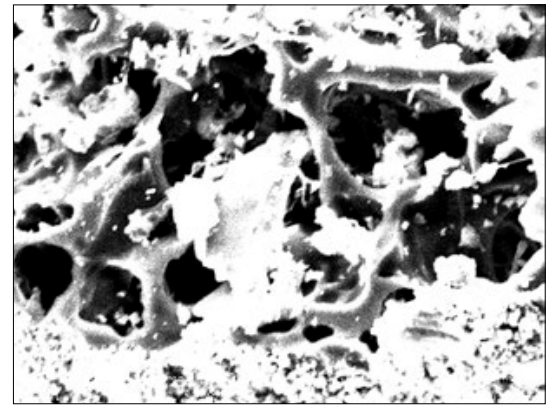

Рисунок 1 - Микрофоотографрия активированного угля,полученного из рисовойшелухиинефтешлама

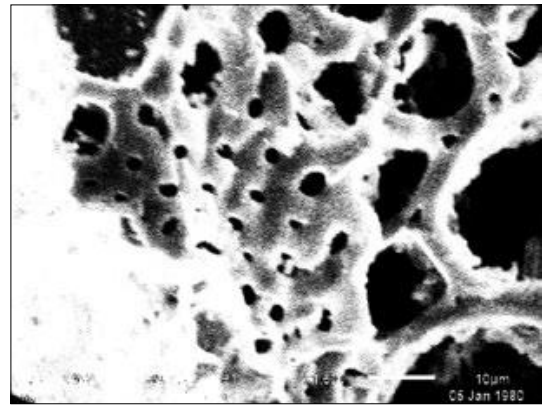

Рисунок 2 - Микрофотография активированного угля,полученного со-термолизом рисовой соломы и нефтешлама 
По результатам экспериментальных исследований, полученный продукт при совместной переработке рисовой шелухи и нефтешлама в соотношениях 9:1 соответствует активированному углю марки ДАК (ГОСТ 6217-74. Уголь активный древесный дробленый). Полученный продукт при совместной переработке рисовой соломы и нефтешлама в соотношениях 9:1, при температуре карбонизации $500^{\circ} \mathrm{C} \mathrm{c}$ продолжительностью 100 мин., при температуре активации $850^{\circ} \mathrm{C}$ в соотношении вода:карбонизат $=2: 1$ (самый оптимальный) соответствует активированным углям марки БАУ-МФ, БАУ-А и БАУ-Ац (ГОСТ 6217-74. Уголь активный древесный дробленый).

Использование предлагаемых способов получения активированного угля, по сравнению с известным способом, обеспечивает высокую адсорбционную активность и в качестве сырья предлагается использовать рисовую шелуху и солому с нефтешламом. Результаты исследований позволяют рационально использовать природные ресурсы и имеют природоохранное значение.

Работа выполнена при поддержке Комитета науки МОН РК за счет грантового финансирования АР05134356.

\section{ЛИТЕРАТУРА}

[1] Кинле Х., Бадер Э. Активные уәли и их промышленное применение. Л.: Химия; 1984. 216 c. [Kinle Kh., Bader E. Active coals and their industrial applications. Leningrad: Khimiya; 1984.].

[2] Arezou Niksiar, Bahram Nasernejad. Activated carbon preparation from pistachio shell pyrolysis and gasification in a spouted bed reactor. Biomass and Bioenergy. 2017;106:4350. DOI: 10.1016 / j.biombioe.2017.08.017.

[3] Yeru Liang, Chen Yang, Hanwu Dong, Wenqi Li, Hang Hu, Yong Xiao, Mingtao Zheng, Yingliang Liu. Facile Synthesis of Highly Porous Carbon from Rice Husk. ACS Sustainable Chem. Eng., Just Accepted Manuscript. 2017;5(8):7111-7117. DOI: 10.1021 I acssuschemeng.7b01315.

[4] Wenli Zhang, Nan Lin, Debo Liu, Jinhui Xu, Jinxin Sha, Jian Yin, Xiaobo Tan, Huiping Yang, Haiyan Lu, Haibo Lin. Direct carbonization of rice husk to prepare porous carbon for supercapacitor applications. Energy. 2017;128: 618-625. DOI: 10.1016 / j.energy.2017.04.065.

[5] Mansurov Z.A., Mansurova R.M.,Nikolayeva A.F., Vasil'yev D.G. Sposob polucheniya karbonizirovannogo sorbenta dlya izvlecheniya zolota iz rastvorov [Пред.патент РК № 15933. Method for obtaining a carbonized sorbent for extracting gold from solutions]. Patent RK, no 15933, 2005.

[6] Khoang Kim Bong, Timofeyev V.S., Tomkin O.N., Gafarov I.G., Timoshenko A.V., Artamonova T.V., Gorbacheva O.V., Kol'vakh I.P., Mishulin G.M., Shchepakin M.B., Kozhura Ye.A., Khaziyev R.M., Vatolin A.K. Sposob polucheniya aktivirovannogo uglya iz othodov sel'skogo hozyajstva [Method for producing activated carbon from agricultural waste] Patent RF, no 2315712, 2008.

[7] Mukhin V.M., Voropayeva N.L., Karpachev V.V., Kharlamov S.A., Spiridonov YU.YA., Gur'yanov V.V., Dmitryakova Ye.Ye. Sposob polucheniya aktivnogo uglya iz rastitel'nyh othodov [Method for producing activated carbon from agricultural waste]. Patent RF, no 2527221, 2014. 
[8] Aworn, A. Preparation of $\mathrm{CO}_{2}$ activated carbon from corncob for monoethylene glycol adsorption. Colloids and Surfaces A: Physicochem and Eng. Asp. 2009;333(1-3):19-25.

[9] Chang, Ch-F. Effects of Burn-off and Activation Temperature on Preparation of Activated Carbon from Corn Cob Agrowaste by $\mathrm{CO} 2$ and Steam. Journal of Colloid and Interface Science. 2000;232(1):45-49.

[10] Hanum F., Bani O., Wirani L.I. Characterization of Activated Carbon from Rice Husk by $\mathrm{HCl}$ Activation and Its Application for Lead $(\mathrm{Pb})$ Removal in Car Battery Wastewater. IOP Conf. Series: Materials Science and Engineering. 2017. V. 180. 012151. DOI: 10.1088 / 1757-899X / 180 / 1 / 012151.

[11] Hanum F., Bani O., Izdiharo A.M. Characterization of Sodium Carbonate $\left(\mathrm{Na}_{2} \mathrm{CO}_{3}\right)$ Treated Rice Husk Activated Carbon and Adsorption of Lead from Car Battery Wastewater. IOP Conf. Series: Materials Science and Engineering. 2017. V. 180, 012149. DOI: 10.1088 / 1757-899X / 180 / 1 / 012149.

[12] Klushin V.N., Tkhu Aung Si, Mukhin V.M., Vin M'int So, Nistratov A.V., Voropayeva N.L. Пaтент РФ № 2609802 на изобретение. Sposob polucheniya aktivnogo uglya iz rastitel'nogo syr'ya [Method for obtaining active coal from vegetable raw materials]. Patent RF, no 2609802, 2017.

[13] Daifullah A.A.M., Girgis B.S., Gad H.M.H. A study of the factors affecting the removal of humic acid by activated carbon prepared from biomass material. Colloids and Surfaces A: Physicochemical and Engineering Aspects. 2004;235(1-3):1-10. DOI: 10.1016 / j.colsurfa.2003.12.020.

[14] Mohamed M.M. Acid dye removal: comparison of surfactant-modified mesoporous FSM16 with activated carbon derived from rice husk. Journal of Colloid and Interface Science. 2004;272(1):28-34. DOI: 10.1016 / j.jcis.2003.08.071.

[15] Rahman I.A. Saad B., Shaidan S., Sya Rizal E.S. Adsorption characteristics of malachite green on activated carbon derived from rice husks produced by chemical-thermal process. Bioresource Technology. 2005;96(14):1578-1583. DOI: 10.1016/j.biortech.2004.12.015.

[16] Kennedy L.J., Vijaya J.J., Sekaran G. Effect of Two-Stage Process on the Preparation and Characterization of Porous Carbon Composite from Rice Husk by Phosphoric Acid Activation. Ind. Eng. Chem. Res. 2004;43(8):1832-1838. DOI: 10.1021 / ie034093f.

[17] Guo Y.Rockstraw D.A. Activated carbons prepared from rice hull by one-step phosphoric acid activation. Microporous and Mesoporous Materials. 2007;100(1-3):12-19. DOI: 10.1016 / j.micromeso.2006.10.006.

[18] Appazov N.O., ZhusupbekU.A., TurmanovR.A., Lyubchik S.B., LyubchikA.I., Lyubchik S.I., Lygina O.S., Baynazarova S.R., Bazarbayev B.M. Sposob polucheniya aktivirovannogo uglya iz risovoy solomy i shelukhi. Promyshl. sobstvennost' [[Method for producing activated carbon from rice straw and hus]. Patent KZ, no 3892, 2019.

[19] Аппазов Н.О., Турманов Р.А., Жаппарбергенов Р.У., Диярова Б.М., Лыгина О.С., Шурагазиева А.Т., Акылбеков Н.И. Получение активированного угля со-термолизом рисовойшелухи и нефтешлама. Химическийжурнал Казахстана. 2019;4(68):77-83. [Appazov N.O., Turmanov R.A., Zhapparbergenov R.U., Dijarova B.M., Lygina O.S., Shuragazieva A.T., Akylbekov N.I. Production of activated carbon by co-thermolysis of rice husks and oil sludge. Himicheskij zhurnal Kazahstana / Chemical Journal of Kazakhstan. 2019;4(68):77-83.].

[20] Appazov, N.O. Obtaining activated carbon by co-termolysis of rice straw and oil sludge / N.O. Appazov, O.S. Lygina, B.M. Bazarbayev, A.T. Shuragaziyeva, N.I. Akylbekov. Bulletin of the Korkyt Ata Kyzylorda State University. 2019; 2(53):35-38.

[21] Аппазов Н.О. Получение активированного угля со-термолизом рисовой соломы и 
нефтешлама. Химический журнал Казахстана. 2019;4(68):46-51. [Appazov, N.O. Production of activated carbon by co-thermolysis of rice straw and oil sludge. Himicheskij zhurnal Kazahstana / Chemical Journal of Kazakhstan. 2019;4(68):46-51.].

[22] Appazov, N.O. Application of microwave irradiation for producing amorphous silicon dioxide from rice husk. Bulletin of the KorkytAta Kyzylorda State University. 2019;2(53):43-46.

[23] Бисенов К.А. Эколого-экономические перспективы использования нефтешламов в составе керамзита. Новости науки Казахстана/Science News of Kazakhstan. 2017;2 (132):79-89. [Bisenov K.A. Ecological and economic prospects for the use of oil sludge as a part of expanded clay. Novosti nauki Kazahstana. 2017;2 (132):79-89.].

[24] Бисенов, К.А. Ресурсосберегающие технологии эффектной утилизации отходов нефтедобычи. Нефрть и газ. 2017;3:128-138. [BisenovK.A. Resource-saving technologies for efficient utilization of oil production waste. Neft' i gaz / Oil and gas. 2017;3:128-138.].

[25] Хайрудинов И.Р. Методы переработки нефтеотходов и нефтешламов. М.: Химия; 1989. 425 c. [Hajrudinov I.R. Methods for processing oil waste and oil sludge. Moscow: Himija; 1989.].

[26] GOST6217. The active coal crushed wood. Technical conditions. Moscow: IPK Izdatel'stvo standartov, 2003. (In Russian).

[27] GOST 17219. The active coals. Method for determining the total pore volume by water. Moscow: Izdatel'stvo standartov, 1988. (In Russian).

[28] GOST 12597. Sorbents. Method for determining the mass fraction of water in active coals and catalysts based on them. Moscow: Izdatel'stvo standartov, 1989. (In Russian).

[29] GOST 16190. Sorbents. Method for determining bulk density. Moscow: Izdatel'stvo standartov, 1970. (In Russian). 